\title{
Virologic response of treatment experienced HIV-infected Ugandan children and adolescents on NNRTI based first-line regimen, previously monitored without viral load
}

Phionah Kibalama Ssemambo ${ }^{1 *}$ D, Mary Gorrethy Nalubega-Mboowa ${ }^{1,2,3}$, Arthur Owora ${ }^{1,4}$, Robert Serunjogi $i^{1}$, Susan Kironde ${ }^{2}$, Sarah Nakabuye ${ }^{1}$, Francis Ssozi ${ }^{2}$, Maria Nannyonga ${ }^{2}$, Philippa Musoke ${ }^{1,5}$ and Linda Barlow-Mosha ${ }^{1}$

\begin{abstract}
Background: Many HIV-infected African children gained access to antiretroviral treatment (ART) through expansion of PEPFAR programs since 2004 and introduction of "Test and Treat" WHO guidelines in 2015. As ART access increases and children transition from adolescence to adulthood, treatment failure is inevitable. Viral load (VL) monitoring in Uganda was introduced in 2016 replacing clinical monitoring. However, there's limited data on the comparative effectiveness of these two strategies among HIV-infected children in resource-limited settings (RLS).

Methods: HIV-infected Ugandan children aged 1-12 years from HIV-care programs with $\geq 1$ year of first-line ART using only immunologic and clinical criteria to monitor response to treatment were screened in 2010. Eligible children were stratified by $V L \leq 400$ and $>400$ copies $/ \mathrm{ml}$ randomized to clinical and immunological (control) versus clinical, immunological and VL monitoring to determine treatment failure with follow-up at 12, 24, 36, and 48 weeks. Plasma VL was analyzed retrospectively for controls. Mixed-effects logistic regression models were used to compare the prevalence of viral suppression between study arms and identify factors associated with viral suppression.

Results: At baseline all children ( $n=142)$ were on NNRTI based ART (75\% Nevirapine, 25\% efavirenz). One third of ART-experienced children had detectable VL at baseline despite high CD4\%. Median age was 6 years (interquartile range [IQR]: $5-9$ ) and $43 \%$ were female. Overall, the odds of viral suppression were not different between study arms: (arm by week interaction, $p=0.63$ ), adjusted odds ratio [aOR]: $1.07 ; 95 \% \mathrm{Cl}: 0.53,2.17, p=0.57$ ) and did not change over time (aOR: 0 vs 24 week: 1.15; $95 \%$ Cl: $0.91,1.46, p=0.24$ and 0 vs 48 weeks: $1.26 ; 95 \%$ Cl: $0.92,1.74$, $p=0.15$ ). Longer duration of a child's ART exposure was associated with lower odds of viral suppression (aOR: 0.61; $95 \%$ Cl: $0.42,0.87, p<.01)$. Only $13 \%$ (9/71) of children with virologic failure were switched to second-line ART, in (Continued on next page)
\end{abstract}

\footnotetext{
*Correspondence: pkibalama@mujhu.org; http://www.mujhu.org

'Makerere University-Johns Hopkins University (MU-JHU) Research

Collaboration, Upper Mulago Hill Road, Mulago, P.O.BOX 23491, Kampala,

Uganda

Full list of author information is available at the end of the article
}

C C The Author(s). 2021 Open Access This article is licensed under a Creative Commons Attribution 4.0 International License, which permits use, sharing, adaptation, distribution and reproduction in any medium or format, as long as you give appropriate credit to the original author(s) and the source, provide a link to the Creative Commons licence, and indicate if changes were made. The images or other third party material in this article are included in the article's Creative Commons licence, unless indicated otherwise in a credit line to the material. If material is not included in the article's Creative Commons licence and your intended use is not permitted by statutory regulation or exceeds the permitted use, you will need to obtain permission directly from the copyright holder. To view a copy of this licence, visit http://creativecommons.org/licenses/by/4.0/ The Creative Commons Public Domain Dedication waiver (http://creativecommons.org/publicdomain/zero/1.0/) applies to the data made available in this article, unless otherwise stated in a credit line to the data. 
(Continued from previous page)

spite of access to real-time VL.

Conclusion: With increasing ART exposure, viral load monitoring is critical for early detection of treatment failure in RLS. Clinicians need to make timely informed decisions to switch failing children to second-line ART.

Trial registration: ClinicalTrials.gov NCT04489953, 28 Jul 2020. Retrospectively registered. (https://register. clinicaltrials.gov).

Keywords: HIV, Antiretroviral therapy, Children and adolescents, Second-line, Switch, viral load, treatment failure, monitoring \& response

\section{Background}

The 2017 UNAIDS report estimated that 2.1 million children under the age of 15 years were living with HIV, with the majority of these living in Sub-Saharan Africa. Currently in Uganda, an estimated 47\% of children living with HIV are receiving antiretroviral therapy (ART) [1]. Although ART became available about a decade ago, accessibility and coverage among treatment-eligible children and adolescents in resource-limited settings is lower than adults with $60 \%$ of eligible children receiving ART compared to $84 \%$ adults [2-6]. Efforts made towards stepping up access to first-line ART have led to positive immunological and virologic outcomes with more children maintained on ART for a longer period of time into adolescence and adulthood [7-9]. However, prolonged use of ART predisposes these children to treatment failure over time [10-13].

Monitoring response to therapy in HIV-infected children has previously been done using CD4 cell counts (immunologic) and clinical criteria because of limited access, lack of technical expertise, inadequate laboratory infrastructure and the high costs associated with viral load testing. This was linked to missed opportunities for timely identification of virologic failure and switch to second-line ART among candidate children (i.e. those who may have benefited from second-line ARV therapy), therefore paving way for emergence of drug resistance [14-17]. In Uganda, the use of immunologic criteria to determine when to switch to second-line ART had low sensitivity $(13 \%)$ as a marker of viral suppression $[18,19]$. Currently, WHO recommends virologic monitoring as the gold standard for diagnosing treatment failure [20, 21]. This is in anticipation of more children with poor response to ART being identified on time and given the appropriate management to improve overall survival and quality of life. In 2016, Uganda began implementing viral load testing for all pediatric patients on ART twice a year [22, 23].

Although there have been some studies done in low income countries that have highlighted the importance of measuring viral load as a more robust method of monitoring response to ART in resource limited settings [24-28], little evidence exists for the effectiveness of such a practice among treatment experienced children previously monitored without viral loads (VL), in resource limited settings. Unlike recent ART initiators, treatment-experienced children may have been maintained on a failing regimen for a considerable amount of time without documentation of virologic failure (based on clinical and immunologic information). Therefore, the objectives of this study were to (1) compare the prevalence of viral suppression and associated predictors between ART treatment-experienced children randomized to either clinical and immunological (control arm) or clinical, immunological plus VL monitoring (intervention arm) and (2) compare prevalence and correlates of decisions to switch to second-line ART between the two study arms at 12, 24, 36, and 48 weeks of follow-up.

\section{Methods \\ Study design}

We conducted a two-center, parallel-group randomized clinical trial study in Kampala, Uganda. The study adhered to CONSORT guidelines. HIV-infected children between the ages 1 and 12 years on ART were randomly assigned using a computer-generated list of random numbers (by the study statistician). Randomization was implemented in blocks $($ size $=4)$ stratified based on baseline VL $(\leq 400$ and $>400 \mathrm{HIV}$ RNA copies $/ \mathrm{ml}$ ) to one of two parallel groups - clinical and immunological versus clinical, immunological plus virologic (VL) monitoring for treatment failure with a 1:1 allocation ratio. The allocation sequence was concealed from study staff enrolling participants to prevent selection bias. Study staff involved in the clinical care were aware of a participant's randomly allocated group due to the nature of study intervention (i.e. monitoring treatment effectiveness) but participants were kept blinded to their group allocation to prevent the likelihood of behavior modification (e.g., adherence) due to knowledge of group assignment. An independent data safety monitoring committee reviewed unblinded data for patient safety; no interim analyses for efficacy or futility were performed.

\section{Eligibility/exclusion criteria}

Eligible participants were HIV-infected children aged 1-12 years who (1) had a duration of at least 12 months on a first-line ART therapy and (2) were being monitored under 
a clinical and immunologic protocol to inform ART regimen change decisions prior to study enrollment. Exclusion was based on the use of second-line ART or PI-based regimen as first-line ART treatment, met immunologic criteria for second-line ART, active TB treatment, liver function tests (AST/ALT) $\geq$ Grade $3 *$ (5.1-10 times ULN or greater), and creatinine $\geq$ Grade $3^{*}$ (1.9-3.4 times ULN or greater) per DAIDS table for grading the Severity of Adult and Pediatric Adverse Events, Version 1.0, Dated December 2004, Clarification August, 2009.

\section{Study setting}

The study took place at two HIV care centers - Makerere University-Johns Hopkins University (MU-JHU) Research Collaboration/MTCT-Plus program and Nsambya Home Care (NHC) in Kampala, Uganda.

\section{Study intervention}

We enrolled 142 ART-experienced HIV-infected children aged 1-12 years, from an existing treatment program that used clinical and immunologic criteria to monitor response to ART in Kampala, Uganda into the study. The 71 children randomly assigned to each study arm underwent laboratory and clinical evaluations every 12 weeks during the 48 weeks follow-up period. Plasma HIV-1 RNA levels were measured at the MU-JHU Core laboratory with the use of the standard Roche Amplicor v1.5 test kit for the children in the clinical, immunologic \& virologic arm.

At screening, viral load was assessed but clinicians were blinded prior to randomization. Information on baseline characteristics of the children including; type of ART, prior PMTCT Nevirapine (NVP) exposure, length on ART, clinical and immunological status, and demography were collected. At enrollment and during scheduled follow up visits; medical history, physical examination and information on child's growth i.e. weight and height, was also collected on standardized study source forms.

Adherence monitoring during study follow up was done using self-report by the caretaker and child where applicable, pill counts at the scheduled visits and crosschecked with pharmacy records. For participants who had adherence challenges, unannounced pill counts were conducted during home visits.

The children remained on their first-line antiretroviral regimen until they were determined to have treatment failure. Since drug resistance testing was not done in real time, the decision to switch was made based on the assignment of monitoring arm. For Arm 1 this was based on; inadequate weight gain and or increasing WHO clinical staging (new or recurrent WHO clinical stage 3 or 4 events), CD4 values falling to $<200$ cells $/ \mathrm{mm}^{3}$ or CD4 percent $<10 \%$ for a child aged between 2 and 5 years of age, CD4 count of $<100$ cell $/ \mathrm{mm}^{3}$ for a child aged 5 years and above. For Arm 2 this was based on; confirmed viral load > 1000 HIV RNA copies/ml; as well as clinical and immunologic criteria described above. Having 2 confirmed viral loads $>1000$ HIV RNA copies/ml at least 2 weeks apart confirmed a virologic endpoint in the study. Clinicians continued participants on first line regimen if viral load is $<5000$ HIV RNA copies/ml as per the 2010 WHO guidelines.

\section{Statistical analysis}

The distribution of study participant characteristics in the overall study sample and differences between study arms were examined to validate study randomization procedures respectively.

All data analyses were conducted based on the intentto-treat protocol. Mixed-effects logistic regression models were used to compare the odds (prevalence) of viral suppression between the two study arms over time. Each child was modeled as a random effect nested within treatment group. Time was modeled as a categorical variable.

Changes in the odds (prevalence) of viral suppression by study arm assignment were examined by testing the significance of the study arm $\mathrm{x}$ week interaction term with and without adjustment for potential confounders. In the absence of statistically significant interactions (at a Type I error rate of 0.05), independent study arm, week and other child characteristic effects were examined and reported. A six-step directed acyclic graph (DAG) approach [29] was used to inform final model covariate selection to reduce the potential for and degree of bias (i.e. confounding and incorrect adjustments for mediators of intervention effects on viral suppression).

Similar procedures described above were used to compare the odds of switching a child to second- line ART regimens between the two study arms and identify correlates of ART change decisions. Missing values in predictor variables were imputed using an $\mathrm{R}$ package called MICE 2.22 [30]. MICE function utilizes an approach of chained equations to impute incomplete multivariate data. Final statistical model results were generated using SAS 9.4 (SAS Institute Inc., Cary, North Carolina) with the level of significance set at the 0.05 level.

\section{Results}

Baseline and follow-up summary characteristics

Overall, 142 children were enrolled in the study and were evenly randomized to either the clinical + immunologic (control) or clinical + immunologic + virologic (intervention) monitoring study arm. The distribution of baseline characteristics did not differ by study arm (Table 1). Descriptive statistics by study arm for viral suppression (defined by $<1000$ copies $/ \mathrm{ml}$ ), time- 
Table 1 Baseline characteristics of study participants (HIV-infected children) by randomized study arm assignment ( $N=142)$

\begin{tabular}{|c|c|c|c|c|}
\hline Characteristic & Overall & $\begin{array}{l}\text { Clinical \& Immunologic } \\
(N=71)\end{array}$ & $\begin{array}{l}\text { Clinical, Immunologic \& } \\
\text { Virologic }(N=71)\end{array}$ & $P$ value \\
\hline \multicolumn{5}{|l|}{ Study Site: n (\%) } \\
\hline Mulago & $70(49)$ & $35(49)$ & $35(49)$ & $1.000^{\mathrm{a}}$ \\
\hline Nsambya & $72(51)$ & $36(51)$ & $36(51)$ & \\
\hline Age in years: Median (IQR) & $6(5,9)$ & $6(5,8)$ & $7(5,9)$ & $0.269^{b}$ \\
\hline Sex: $n(\%)$ & & & & $0.865^{\mathrm{a}}$ \\
\hline Female & $61(43)$ & $31(43)$ & $30(42)$ & \\
\hline Male & $81(57)$ & $40(56)$ & $41(58)$ & \\
\hline WHO Stage: n (\%) & & & & $0.947^{c}$ \\
\hline 1 & $22(15)$ & $12(17)$ & $10(14)$ & \\
\hline 2 & $57(40)$ & $29(41)$ & $28(39)$ & \\
\hline 3 & $54(38)$ & $26(37)$ & $28(39)$ & \\
\hline 4 & $9(6)$ & $4(6)$ & $5(7)$ & \\
\hline NVP Exposure: n (\%) & & & & $0.938^{c}$ \\
\hline Yes & $53(37)$ & $27(38)$ & $26(37)$ & \\
\hline No & $76(54)$ & $37(52)$ & $39(55)$ & \\
\hline Unknown & $13(9)$ & $7(10)$ & $6(8)$ & \\
\hline In utero ART: n (\%) & & & & $0.960^{c}$ \\
\hline Yes & $43(30)$ & $21(30)$ & $22(31)$ & \\
\hline No & $82(58)$ & $41(58)$ & $41(58)$ & \\
\hline Unknown & $17(12)$ & $9(12)$ & $8(11)$ & \\
\hline HIV RNA copies/ml: n (\%) & & & & $0.722^{\mathrm{a}}$ \\
\hline$\leq 1000$ & $94(66)$ & $46(65)$ & $48(68)$ & \\
\hline$>1000$ & $48(34)$ & $25(35)$ & $23(32)$ & \\
\hline HIV RNA copies/ml: n (\%) & & & & $1.000^{a}$ \\
\hline$\leq 400$ & $92(65)$ & $46(65)$ & $46(65)$ & \\
\hline$>400$ & $50(35)$ & $25(35)$ & $25(35)$ & \\
\hline ART Duration in years: Median (IQR) & $4(2,5)$ & $3(2,4)$ & $4(2,5)$ & $0.225^{\mathrm{b}}$ \\
\hline $\begin{array}{l}\text { CD cell count (\%): } \\
\text { Median (IQR) }\end{array}$ & $32(26,38)$ & $33(26,38)$ & $32(27,38)$ & $0.931^{b}$ \\
\hline $\begin{array}{l}\text { Absolute CD4 cell count: } \\
\text { Median (IQR) }\end{array}$ & $\begin{array}{l}1071 \\
(759,1416)\end{array}$ & $\begin{array}{l}1097 \\
(776,1537)\end{array}$ & $\begin{array}{l}1032 \\
(721,1326)\end{array}$ & $0.501^{b}$ \\
\hline $\begin{array}{l}\text { BMI-for-age Z: } \\
\text { Median (IQR) }\end{array}$ & $\begin{array}{l}-0.26 \\
(-0.92,0.36)\end{array}$ & $\begin{array}{l}-0.21 \\
(-1.06,0.43)\end{array}$ & $\begin{array}{l}-0.28 \\
(-0.88,0.29)\end{array}$ & $0.875^{b}$ \\
\hline Weight-for-age Z score: Median (IQR) & $\begin{array}{l}-0.97 \\
(-1.54,-0.25)\end{array}$ & $\begin{array}{l}-0.97 \\
(-1.37,-0.33)\end{array}$ & $\begin{array}{l}-0.99 \\
(-1.63,-0.15)\end{array}$ & $0.933^{b}$ \\
\hline $\begin{array}{l}\text { Height-for-age Z score: } \\
\text { Median (IQR) }\end{array}$ & $\begin{array}{l}-1.07 \\
(-1.92,-0.34)\end{array}$ & $\begin{array}{l}-1.10 \\
(-1.76,-0.28)\end{array}$ & $\begin{array}{l}-1.03 \\
(-1.93,-0.41)\end{array}$ & $0.979^{b}$ \\
\hline
\end{tabular}

Missing: \%CD4-15; Abs CD4-2

${ }^{\mathrm{a} C h i}$-square test; ${ }^{\mathrm{b}}$ Wilcoxon Two-Sample test; ${ }^{\mathrm{c}}$ Fishers-Exact test

independent, and time dependent variables (ARV change, absolute $\mathrm{CD} 4, \mathrm{CD} 4 \%$ ) at baseline, 12, 24, 36 and 48 weeks are also summarized in Table 1.

Of the 142 participants, 129 (91\%) and 134 (94\%) completed the 24- and 48-week assessments, respectively. The intervention study arm (clinical + immunologic + virologic monitoring) had additional assessments at 12 (response rate: 100\%) and 36 (response rate: 96\%) weeks; however, overall, there were no differences in response rate by study arm $(p=0.98)$.

\section{Viral suppression}

Overall, 92 (64\%), 86 (67\%) and 93 (69\%) children had viral suppression at baseline, 24 and 48 weeks 


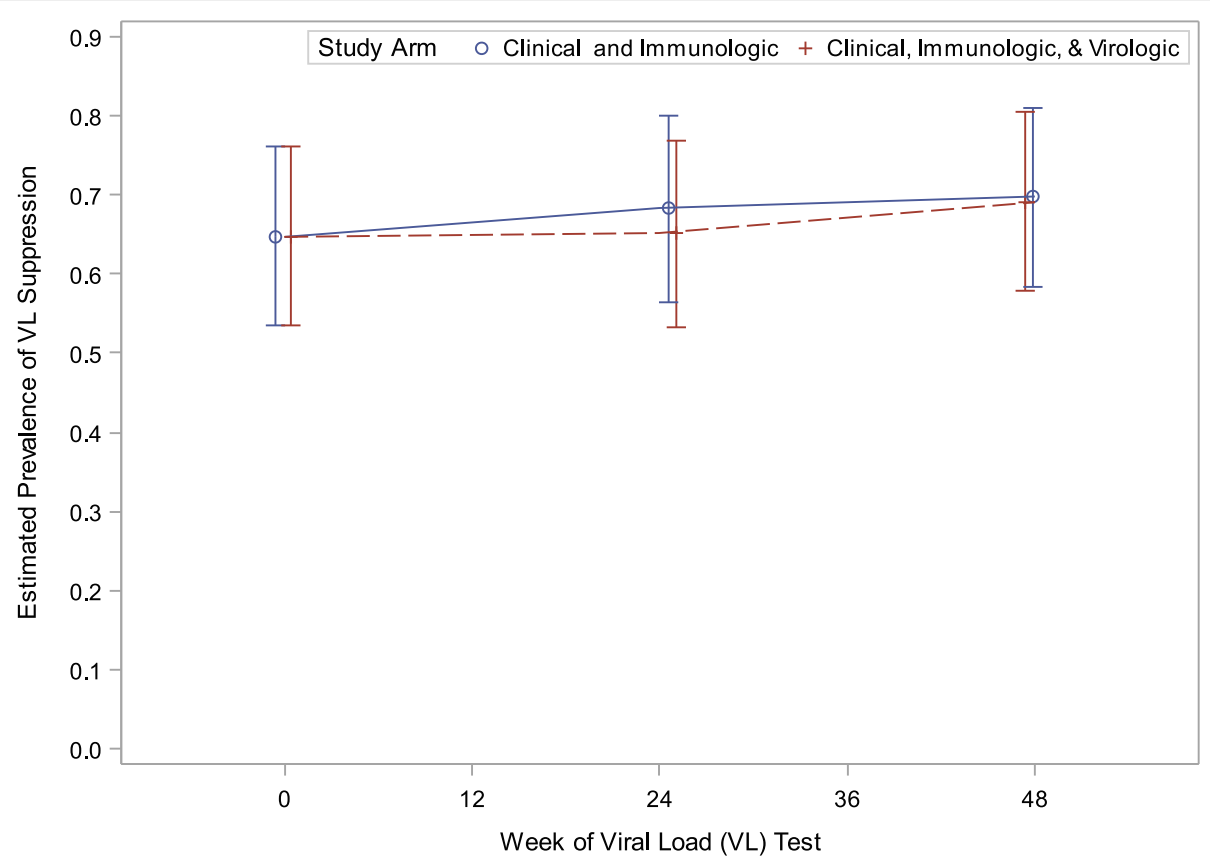

Fig. 1 Estimated prevalence of viral load suppression (<400 copies/ml) by study arm during a 48-week follow-up

respectively. The prevalence of viral suppression did not differ by study arm during follow-up (study arm $\mathrm{x}$ week interaction term: $p=0.63$ ). Overall, the odds of viral suppression were not different between study arms (Clinical, Immunologic \& Virologic) vs Clinical \& Immunologic (Fig. 1):
[aOR]: 1.07; 95\%CI: $0.53,2.17, p=0.57)$ and did not change over time [Fig. 2] (aOR: 0 vs 24 week: 1.15 ; $95 \%$ CI: 0.91 , 1.46, $p=0.24$ and 0 vs 48 weeks: 1.26 ; $95 \%$ CI: $0.92,1.74$, $p=0.15$ ). Having no history of NVP exposure (aOR: 2.75 ; 95\%CI: 1.19, 6.37), higher baseline CD4\% cell count (Fig. 3)

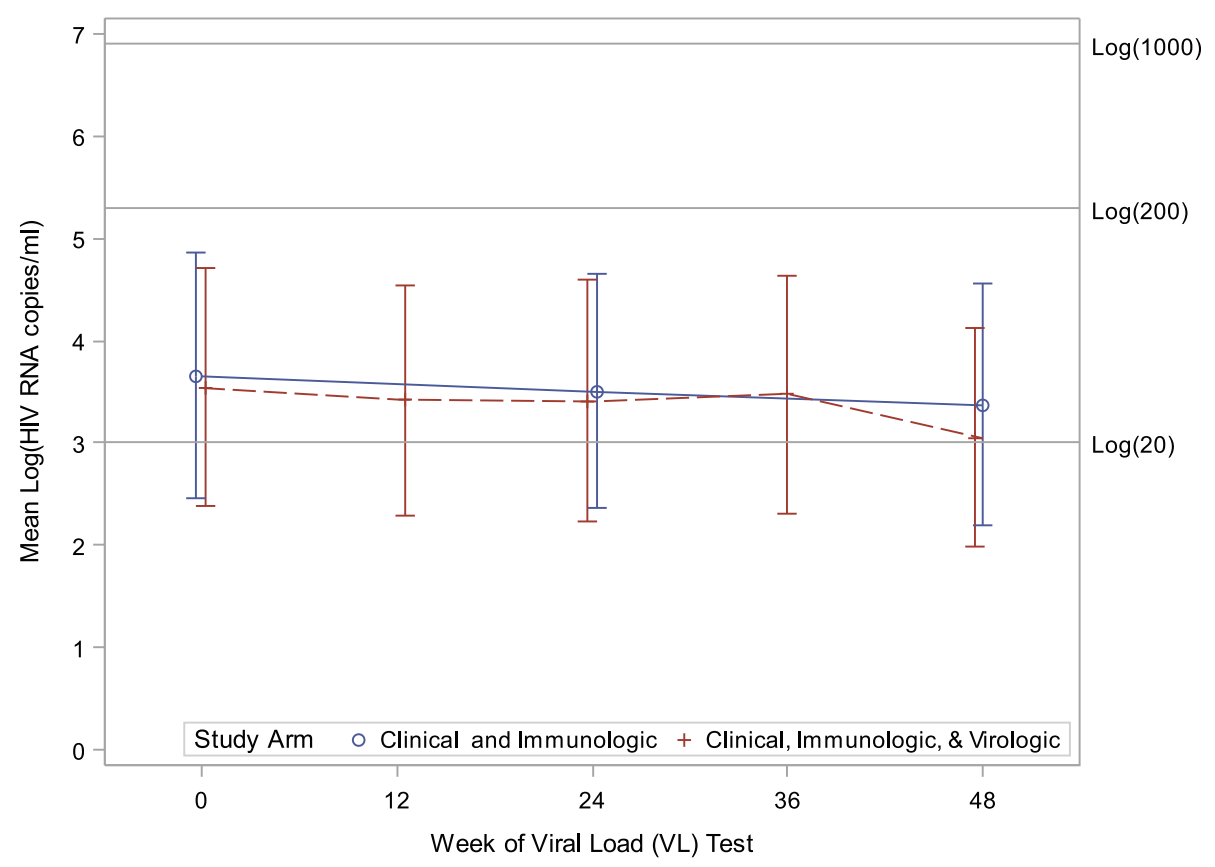

Fig. 2 Mean Log (HIV RNA copies/ml) by study arm during a 48-week follow-up. Undetected virus levels rounded off to 1 copy $/ \mathrm{ml}(\mathrm{log}(1)=0)$. Overall and within-study arm median HIV RNA copies/ml was zero 


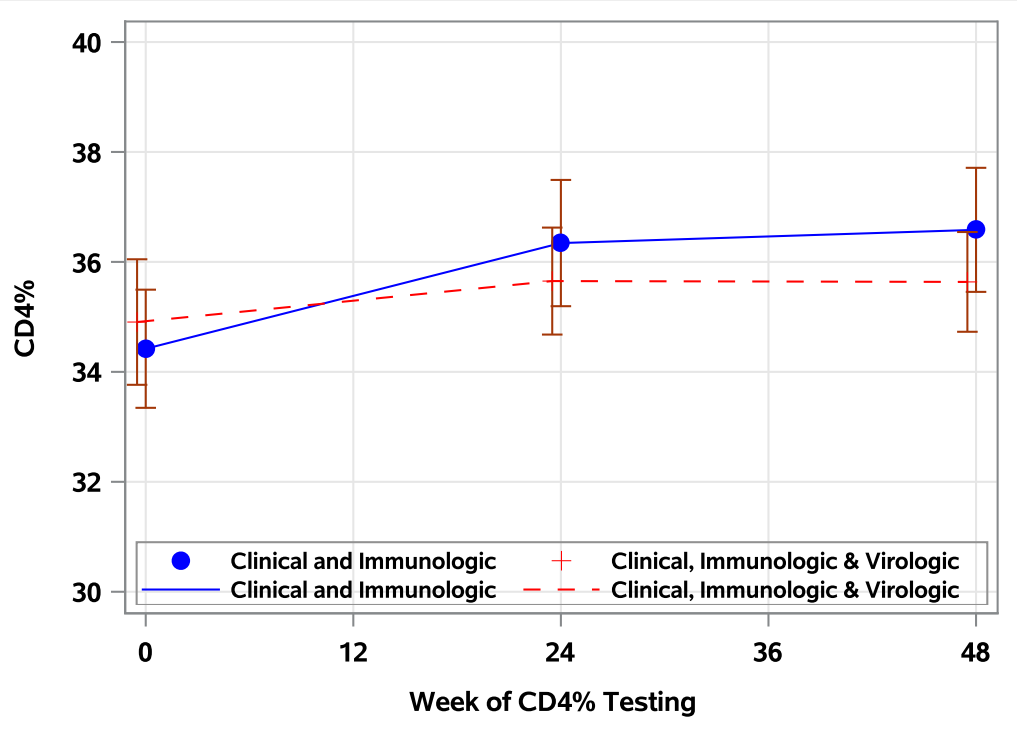

Fig. 3 Mean CD4 cell \% by study arm during a 48-week follow-up

(aOR: 1.09; 95\%CI: 1.04, 1.15) or absolute (log transformed) CD4 count (aOR: 2.75; 95\%CI: 1.17, 15.18) were associated with higher odds of viral suppression over time. Longer durations on ART was associated with lower odds of viral suppression (aOR: 0.67; 95\%CI: 0.49, 0.91). Although, the prevalence of viral suppression was higher among children who had had a drug switch in their ARV regimen (80\%) versus those that did not (66\%) at 24 weeks (Table 2), overall, a change in ARV regimen (defined as 3 drug change to change to second line) did not predict viral suppression over time (aOR: 0.85; 95\% CI: 0.27, 2.73). Study site, age, sex, baseline WHO stage, in-utero ART exposure, ageadjusted BMI, weight and height were not associated with viral suppression over time (Table 2).

\section{ARV changes}

The prevalence of ARV switching during follow-up did not differ by study arm [Fig. 4] (study arm x week interaction term $=0.39)$. Overall, the odds of ARV changes did not differ between study arms ([aOR]: 1.58; 95\%CI: $0.62 ; 4.00)$ but increased over time; the odds of switching a child's ARV regimen were 5.37 (aOR: 95\%CI: 3.02, 7.97) and 24.10 (aOR: 95\%CI: 9.14, 63.56) times higher at 24 and 48 weeks, respectively adjusted for study arm assignment and suspected confounders i.e. (log (HIV RNA copies/ml), study arm, week, NVP exposure, ART duration, and location).

The prevalence of switching to second-line ARV regimens increased over time: 8 and $17 \%$ at 24 and 48 weeks, respectively. The overall odds of switching a child's ARV did not differ by NVP exposure, ART duration and study site (Table 3 ). Changes in viral load and CD4 cell count did not predict switches in ARV regimens either (Table 3).

\section{Discussion}

Recommendation for ART monitoring has gradually changed over time. Initially, patients' CD4 T Cells were monitored every 6 months and viral load testing was only done when possible. Currently, WHO recommends viral load as the preferred monitoring approach to diagnose and confirm treatment failure, with viral load testing being conducted at 6 and 12 months after ART initiation and every 12 months thereafter [31]. Viral load monitoring in children is required every 6 months.

In this analysis of Ugandan children and adolescents, our findings show that the addition of periodic (annual) virologic testing to standard of care (clinical and immunological monitoring) among treatment-experienced HIV infected children was not associated with a higher prevalence of viral suppression. The results do however support the need for virologic monitoring as a better strategy for early detection of virologic failure especially with increased duration of ART exposure, since immunologic monitoring is a poor predictor of treatment failure. Our findings are in agreement with previous Sub-Saharan Africa studies which have shown that clinical and immunologic monitoring is not sufficient to detect virologic failure in a timely manner [14, 16, 32], which further supports the need for viral load testing as a strategy to monitor response to treatment in children. This is similar to findings from a study done in Uganda and Zimbabwe, the ARROW TRIAL which highlighted the importance of confirming virological failure before switching to second-line ART, since some children with detectable low-level viraemia spontaneously re-suppressed [33].

Additionally, our study showed no evidence to suggest virologic testing results in better treatment decisions (i.e. 
Table 2 Prevalence of viral suppression, crude and adjusted odds ratios (with 95\%Cl) summarizing the relationship between selected risk factors and viral suppression during a 48 week follow-up period among HIV-infected children in Uganda ( $N=142)$

\begin{tabular}{|c|c|c|c|c|c|}
\hline \multirow[t]{2}{*}{ Characteristic } & \multicolumn{3}{|c|}{ Viral suppression by week } & \multirow{2}{*}{$\begin{array}{l}\text { Crude Odds Ratio } \\
\text { OR }(95 \% \mathrm{Cl})\end{array}$} & \multirow{2}{*}{$\begin{array}{l}\text { Adjusted Odds Ratio } \\
\text { aOR }(95 \% \mathrm{Cl})\end{array}$} \\
\hline & $\begin{array}{l}\text { Baseline } \\
\text { n (\%) }\end{array}$ & $\begin{array}{l}24 \text { Weeks } \\
\text { n (\%) }\end{array}$ & $\begin{array}{l}48 \text { Weeks } \\
\text { n (\%) }\end{array}$ & & \\
\hline \multicolumn{6}{|l|}{ Monitoring arm } \\
\hline Immunologic & $46(65)$ & $43(68)$ & $46(70)$ & Ref & $\operatorname{Ref}^{a}$ \\
\hline Immunologic \& Virologic & $46(65)$ & $43(65)$ & $47(69)$ & $0.88(0.46 ; 1.69)$ & $1.06(0.47 ; 2.42)$ \\
\hline \multicolumn{6}{|l|}{ ARV Change } \\
\hline No & & $78(66)$ & $77(69)$ & Ref & Ref \\
\hline Yes & & $8(80)$ & $16(70)$ & $1.52(0.59 ; 3.89)$ & $0.85(0.27 ; 2.73)$ \\
\hline \multicolumn{6}{|l|}{ Study Site } \\
\hline Mulago & $43(61)$ & $38(59)$ & $43(63)$ & Ref & $\operatorname{Ref}^{b}$ \\
\hline Nsambya & $49(68)$ & $48(74)$ & $50(76)$ & $1.56(0.82 ; 2.99)$ & $0.70(0.25 ; 1.96)$ \\
\hline \multicolumn{6}{|l|}{ Sex } \\
\hline Female & $39(64)$ & $34(63)$ & $41(69)$ & Ref & $\operatorname{Ref}^{c}$ \\
\hline Male & $53(65)$ & $52(69)$ & $52(69)$ & $1.12(0.58 ; 2.15)$ & $1.01(0.45 ; 2.26)$ \\
\hline \multicolumn{6}{|l|}{ WHO Stage } \\
\hline 1 & $16(73)$ & $12(63)$ & $14(66)$ & Ref & $\operatorname{Ref}^{d}$ \\
\hline 2 & $38(67)$ & $40(78)$ & $40(74)$ & $1.14(0.42 ; 3.09)$ & $0.63(0.17 ; 2.26)$ \\
\hline 3 & $33(61)$ & $31(61)$ & $33(66)$ & $0.74(0.28 ; 1.98)$ & $0.49(0.14 ; 1.66)$ \\
\hline 4 & $5(56)$ & $3(38)$ & $6(67)$ & $0.55(0.13 ; 2.32)$ & $0.28(0.05 ; 1.63)$ \\
\hline \multicolumn{6}{|l|}{ NVP Exposure } \\
\hline Yes & $27(51)$ & $28(55)$ & $28(56)$ & Ref & $\operatorname{Ref}^{\mathrm{e}}$ \\
\hline No & $56(74)$ & $47(72)$ & $55(77)$ & $2.61(1.31 ; 5.21)^{* *}$ & $2.75(1.19 ; 6.37)^{* *}$ \\
\hline Unknown & $9(69)$ & $11(85)$ & $10(77)$ & $2.92(0.83 ; 10.32)$ & \\
\hline \multicolumn{6}{|l|}{ In utero ART } \\
\hline Yes & $27(63)$ & $25(60)$ & $24(57)$ & Ref & $\operatorname{Ref}^{f}$ \\
\hline No & $51(62)$ & $47(65)$ & $54(72)$ & $1.37(0.67 ; 2.77)$ & $1.20(0.53 ; 2.74)$ \\
\hline Unknown & $14(82)$ & $24(93)$ & $15(88)$ & $5.10(1.26 ; 20.61)^{*}$ & - \\
\hline Age (years) & & & & $1.01(0.90 ; 1.16)$ & $1.19(0.97 ; 1.48)^{9}$ \\
\hline ART duration (years) & & & & $0.70(0.56 ; 0.88)^{* *}$ & $0.67(0.49 ; 0.91)^{\mathrm{h}^{*}}$ \\
\hline CD\%/cell count & & & & $1.03(0.99 ; 1.07)$ & $1.09(1.04 ; 1.15)^{i *}$ \\
\hline Log (Absolute CD4) & & & & $2.82(1.39,5.69)^{* *}$ & $2.75(1.17 ; 15.18)^{i *}$ \\
\hline BMI-for-age Z: & & & & $0.79(0.61 ; 1.01)$ & $0.85(0.62 ; 1.15)^{j}$ \\
\hline Weight-for-age Z: & & & & $0.96(0.73 ; 1.28)$ & $1.11(0.75 ; 1.64)^{j}$ \\
\hline Height-for-age Z: & & & & $1.21(0.91 ; 1.61)$ & $1.33(0.91 ; 1.93)^{j}$ \\
\hline
\end{tabular}

${ }^{*} p<0.05 ;{ }^{* *} p<0.01$

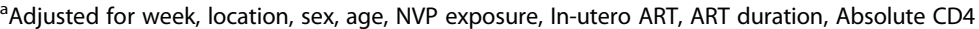

${ }^{\mathrm{b}}$ Adjusted for study arm, week, sex, age, NVP exposure, In-utero ART, ART duration, Absolute CD4

${ }^{c}$ Adjusted for study arm, week, Absolute CD4

${ }^{\mathrm{d}}$ Adjusted for study arm, week, location, sex, and in-utero ART

${ }^{\text {e} A d j u s t e d ~ f o r ~ s t u d y ~ a r m, ~ w e e k, ~ l o c a t i o n, ~ W H O ~ s t a g e, ~ i n-u t e r o ~ A R T, ~ A R T ~ d u r a t i o n ~ a n d ~ B M I-f o r-a g e ~ Z ~}$

${ }^{f}$ Adjusted for study arm, week, and location

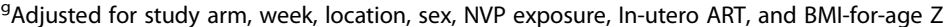

hAdjusted for study arm, week, location, WHO stage, NVP exposure, In-utero ART, and BMI-for-age Z

'Adjusted for study arm, week, location, sex, NVP exposure, In-utero ART, and BMI-for-age Z

jAdjusted for study arm, week, location, sex, NVP exposure, In-utero ART, ART duration and Absolute CD4

${ }^{5}$ ARV Change - Time dependent (varying) variable (adjusted for study arm, week, location, NVP exposure, ART duration and baseline absolute CD4 count) 


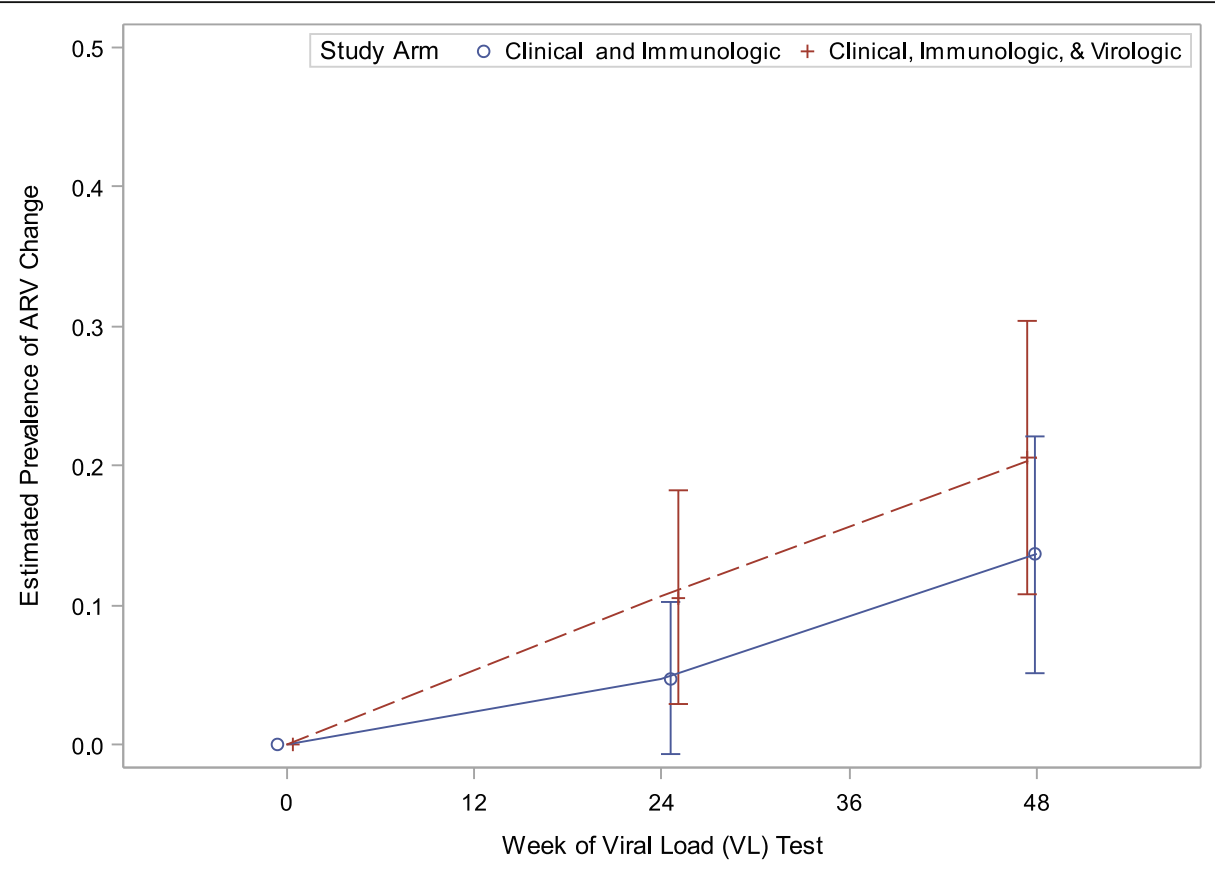

Fig. 4 Estimated prevalence of ARV change by study arm during a 48-week follow-up, Phase I

switching to second-line ARVs) linked to better clinical outcomes (i.e. viral suppression). Although the odds of switching a child's ARV regimen were not different between study arms, the odds of switching to second-line regimens increased over time but were not predicted by a child's treatment exposure history or immunological parameters. Our study highlights the need to operationalize monitoring results into algorithms to inform ARV change decisions since there appears to be a disconnect between monitoring results and actual decisions to switch ARVs.

Independent of study arm assignment, having no history of NVP exposure, higher baseline CD4\% cell count or absolute CD4 count were associated with higher odds of viral suppression over time while longer duration on

Table 3 Prevalence of ARV change, crude and adjusted odds ratios (with 95\% Cl) summarizing the relationship between selected risk factors and ARV change during a 48 week follow-up period among HIV-infected children in Uganda $(N=142)$

\begin{tabular}{|c|c|c|c|c|c|c|}
\hline \multirow[t]{2}{*}{ Characteristic } & \multicolumn{4}{|c|}{ ARV changed by week } & \multirow{2}{*}{$\begin{array}{l}\text { Crude Odds Ratio } \\
\text { OR }(95 \% \mathrm{Cl})\end{array}$} & \multirow{2}{*}{$\begin{array}{l}\text { Adjusted Odds Ratio } \\
\text { OR }(95 \% \mathrm{Cl})\end{array}$} \\
\hline & $\begin{array}{l}12 \\
\text { n (\%) }\end{array}$ & $\begin{array}{l}24 \\
\text { n (\%) }\end{array}$ & $\begin{array}{l}36 \\
\text { n (\%) }\end{array}$ & $\begin{array}{l}48 \\
\text { n (\%) }\end{array}$ & & \\
\hline Overall & $2(1)$ & $10(8)$ & $12(9)$ & $23(17)$ & & \\
\hline \multicolumn{7}{|l|}{ Monitoring arm } \\
\hline Immunologic & - & $3(5)$ & - & $9(14)$ & Ref & Ref \\
\hline Virologic & $2(3)$ & $7(11)$ & $12(18)$ & $14(21)$ & $1.52(0.59 ; 3.89)$ & $1.58(0.62 ; 4.00)^{\mathrm{a}}$ \\
\hline${ }^{\int} \log ($ HIV RNA copies/ml) & & & & & $0.97(0.90 ; 1.05)$ & $1.02(0.92 ; 1.12)^{a}$ \\
\hline Log (ABS CD4) & & & & & $0.91(0.44 ; 1.86)$ & $0.77(0.29 ; 2.00)^{b}$ \\
\hline${ }^{\prime} \mathrm{CD} 4 \%$ & & & & & $0.99(0.96 ; 1.04)$ & $0.97(0.92 ; 1.04)^{b}$ \\
\hline \multicolumn{7}{|l|}{ Week } \\
\hline Baseline & & & & & Ref & $\operatorname{Ref}^{*}$ \\
\hline 24 & & & & & $1.91(1.19 ; 3.07)$ & $5.37(3.02 ; 7.97)^{a}$ \\
\hline 48 & & & & & $3.65(1.40 ; 9.45)$ & $24.10(9.14 ; 63.56)^{a}$ \\
\hline
\end{tabular}

${ }^{*} p<0.05 ;{ }^{* *} p<0.01$

Participants who had an ARV change are counted in the prevalence estimate at subsequent follow-up

${ }^{a}$ Covariates in the final adjusted model: log (HIV RNA copies/ml), study arm, week, NVP exposure, ART duration, and location

${ }^{b}$ Covariates in the final adjusted model: study arm, week, NVP exposure, ART duration, and location

${ }^{\text {s }}$ Time dependent variable 
ART was associated with lower odds of viral suppression. A similar study done in Tanzania in perinatally HIV infected children [34] also showed that longer duration on ART was associated with poor virologic outcomes due to selection of resistance mutations making their virus more difficult to suppress. This NNRTI resistance pattern is very common in many countries, Uganda inclusive where non-nucleoside reverse transcriptase inhibitors (NNRTIs) of which nevirapine is part were used as part of a first-line ART regimen. In addition, children in this study were exposed to single dose nevirapine for PMTCT and their mothers also received nevirapine which could have lowered their odds of virologic suppression, a trend consistent with previous studies [35-38]; this may explain our null intervention effect [39, 40].

In contrast to previous studies [41, 42], our study findings suggest that the addition of periodic (annual) virologic testing did not change the prevalence of ART switching decisions between the two study arms, although the viral load monitoring was able to identify virological failure sooner than the ones who were monitored clinically and immunologically. The delay in switching could have been due to lack of clear guidelines at the time on when to switch, limited ART options and lack of confidence on the part of the health care providers to switch ART. The number of children switched to second-line ART was small in this study and if only immunological monitoring was used to determine when to switch to second-line ART, the percentage of children switched to second-line ART would have been much less. Viral load monitoring should be utilized to identify treatment failure early and thereafter make the necessary changes (28) which would reduce accumulation of drug resistance mutations and limited treatment options for second-line ART (29).

The strengths of this study include the longitudinal laboratory and clinical monitoring as well as the high rates of follow up with minimal losses to follow up during the 48-week period. The children in the two arms were comparable in terms of baseline characteristics and virologic suppression at baseline.

The limitations of this study include the partial blinding, the short follow up period of 48 weeks and a relatively small sample size of perinatally HIV infected children and adolescents, which may not be generalizable to all ART experienced children. Both the study staff enrolling participants and the participants were blinded to the assignment however, the clinical care staff were not. This could have influenced the behaviour of study staff towards participants. Longer duration of follow up and a larger sample size would confirm the findings of this study. However, the current guidelines and practice recommend that all children on ART should have routine VL monitoring.

\section{Conclusion}

The results of this study confirm that virologic monitoring is a superior strategy for detecting early HIV treatment failure especially with the increasing duration of ART exposure among adolescents and lend credence and support to the current WHO guidelines on ART monitoring. The issue of availability and cost of viral load testing still remains a challenge, especially in high burden countries in Sub-Saharan Africa. Therefore, studies to evaluate the affordability and accessibility of these services in resource limited settings will further inform the current WHO recommendations. In addition, there is need to operationalize monitoring results into algorithms to inform ART change decisions since there appears to be a disconnect between monitoring results and actual decisions to switch ART by health workers after ART treatment failure is identified.

\section{Abbreviations \\ ART: Antiretroviral treatment; VL: Viral load; IQR: Interquartile range; aOR: Adjusted odds ratio; RLS: Resource limited settings}

\section{Acknowledgements}

We thank the children, their families, and their caregivers who agreed to participate In the TIBOTEC and Optimal Care Study. We would like to acknowledge the staff based at Nsambya Home Care (NHC) and Makerere University-Johns Hopkins University (MU-JHU) under the leadership of Dr. Linda Barlow-Mosha (Tibotec REACH Initiatives recipient and Thrasher Research Fund \# 9415) without whose dedication this study could not have been done. We also acknowledge all the support offered by MUJHU regulatory team while ensuring quality of the study findings. We sincerely appreciate the Tibotec REACH Initiatives and Thrasher award foundation for funding this study. The content is solely the responsibility of the authors and does not necessarily represent the views of the Tibotec REACH Initiatives and Thrasher award.

\section{Authors' contributions}

LBM, and PM, served as protocol co-chairs on the protocol team for the study and provided oversight in its design, implementation, and dissemination. They also assisted in data interpretation, and critically revised the manuscript. MN, PKS, MGNM, SK, FS, SN, oversaw study activities at our recruitment sites and critically revised the manuscript. OA, RS, PKS, MGNM, designed the analysis, interpreted the data, and wrote the manuscript. MM, RS, OA, managed study data, conducted statistical analysis, and critically revised the manuscript. All authors have reviewed and approved the submitted version of the manuscript. Members of the writing team had full access to all the data in the study. The corresponding author had final responsibility for the decision to submit for publication.

\section{Funding}

This study was funded by the Thrasher Research Fund Award Grant: 9415, with baseline study funding from Tibotec REACH Initiative. The funding bodies provided funds that were used to cover expenses during study design, data collection, and data analysis.

\section{Availability of data and materials}

All data generated or analyzed during the current study are included in this published article and its supplementary information files. Additionally, the datasets analyzed during the current study may be availed from the corresponding author upon reasonable request.

\section{Declarations}

Ethics approval and consent to participate

The study was approved by the School of Medicine Research Ethics Committee (SOMREC) [REC REF 2009-173] and Uganda National Council for 
Science and Technology [UNCST Ref \#HS 719]. All caretakers provided written informed consent, and children above 8 years provided assent as required by Uganda regulatory guidelines.

\section{Consent for publication}

All caretakers provided written informed consent, and children above 8 years provided assent as required by Uganda regulatory guidelines. Within the consent form that was read and signed by the caretakers, there was a section about results from the study being published while maintaining participant confidentiality.

\section{Competing interests}

The authors declare that they have no competing interests and have received no payment in preparation of this manuscript.

\section{Author details}

${ }^{1}$ Makerere University-Johns Hopkins University (MU-JHU) Research Collaboration, Upper Mulago Hill Road, Mulago, P.O.BOX 23491, Kampala, Uganda. ${ }^{2}$ Nsambya Home Care Project (NHC), Kampala, Uganda. ${ }^{3}$ Clarke International University (Formerly IHSU), Namuwongo, Kampala, Uganda. ${ }^{4}$ Department of Epidemiology and Biostatistics, School of Public Health, Indiana University, Indiana, USA. ${ }^{5}$ Department of Paediatrics and Child Health, College of Health Sciences, Makerere University, Kampala, Uganda.

\section{Received: 24 June 2020 Accepted: 11 March 2021}

Published online: 22 March 2021

\section{References}

1. UNAIDS, Fact sheet-latest statisitics on the AIDS epidemic. 2017.

2. Sepkowitz KA. AIDS - the first 20 years. N Engl J Med. 2001;344(23):176472. https://doi.org/10.1056/NEJM200106073442306.

3. UNAIDS, UNAIDS_Gap_report_en.pdf. 2016.

4. UNAIDS, ACCESS TO ANTIRETROVIRAL THERAPY IN AFRICA: STATUS REPORT ON PROGRESS TOWARDS THE 2015 TARGETS. 2013, UNAIDS Geneva, Switzerland.

5. WHO, U., UNICEF, GLOBAL HIVAIDS RESPONSE: Epidemic update and health sector progress towards Universal Access. 2011.

6. UNAIDS, UNAIDS DATA. 2017

7. Achhra AC, Phanuphak P, Amin J. Long-term immunological outcomes in treated HIV-infected individuals in high-income and low-middle income countries. Curr Opin HIV AIDS. 2011;6(4):258-65. https://doi.org/10.1097/ $\mathrm{COH} .0 \mathrm{~b} 013 \mathrm{e} 3283476 \mathrm{c} 72$

8. Phongsamart W, Hansudewechakul R, Bunupuradah T, Klinbuayaem V, Teeraananchai S, Prasithsirikul W, Kerr SJ, Akarathum N, Denjunta S, Ananworanich J, Chokephaibulkit K. Long-term outcomes of HIV-infected children in Thailand: the Thailand pediatric HIV observational database. Int J Infect Dis. 2014;22:19-24. https://doi.org/10.1016/j.jiji.2013.12.011.

9. Rouet F, Fassinou P, Inwoley A, et al. Long-term survival and immunovirological response of African HIV-1-infected children to highly active antiretroviral therapy regimens. AIDS Res Ther. 2006:20:2315-9.

10. Bunupuradah T, Sricharoenchai S, Hansudewechakul R, Klinbuayaem V, Teeraananchai S, Wittawatmongkol O, Akarathum N, Prasithsirikul W, Ananworanich J. Risk of first-line antiretroviral therapy failure in HIV-infected Thai children and adolescents. Pediatr Infect Dis J. 2015;34(3):e58-62. https://doi.org/10.1097/INF.0000000000000584.

11. Castro $\mathrm{H}$, et al. Risk of triple-class virological failure in children with HIV: a retrospective cohort study. Lancet. 2011;377(9777):1580-7. https://doi.org/1 0.1016/S0140-6736(11)60208-0.

12. Judd A, Lodwick R, Noguera-Julian A, Gibb DM, Butler K, Costagliola D, Sabin C, van Sighem A, Ledergerber B, Torti C, Mocroft A, Podzamczer D, Dorrucci M, de Wit S, Obel N, Dabis F, Cozzi-Lepri A, García F, Brockmeyer NH, Warszawski J, Gonzalez-Tome MI, Mussini C, Touloumi G, Zangerle R, Ghosn J, Castagna A, Fätkenheuer G, Stephan C, Meyer L, Campbell MA, Chene G, Phillips A, The Pursuing Later Treatment Options II (PLATO I) Project Team for the Collaboration of Observational HIV Epidemiological Research Europe (COHERE) in EuroCoord. Higher rates of triple-class virological failure in perinatally HIV-infected teenagers compared with heterosexually infected young adults in Europe. HIV Med. 2017;18(3):171-80. https://doi.org/10.1111/hiv.12411.

13. Nglazi MD, Kranzer K, Holele P, Kaplan R, Mark D, Jaspan H, Lawn SD, Wood R, Bekker LG. Treatment outcomes in HIV-infected adolescents attending a community-based antiretroviral therapy clinic in South Africa. BMC Infect Dis. 2012;12(1):21. https://doi.org/10.1186/1471-2334-12-21.

14. Emmett SD, et al. Predicting virologic failure among HIV-1-infected children receiving antiretroviral therapy in Tanzania: a cross-sectional study. J Acquir Immune Defic Syndr. 2010;54(4):368-75.

15. Obiri-Yeboah D, Pappoe F, Baidoo I, Arthur F, Hayfron-Benjamin A, Essien-Baidoo S, Kwakye-Nuako G, Ayisi Addo S. Immunologic and virological response to ART among HIV infected individuals at a tertiary hospital in Ghana. BMC Infect Dis. 2018;18(1):230. https://doi.org/10.11 86/s12879-018-3142-5.

16. Ruel TD, et al. Early virologic failure and the development of antiretroviral drug resistance mutations in HIV-infected Ugandan children. J Acquir Immune Defic Syndr. 2011;56(1):44-50.

17. Kukoyi $\mathrm{O}$, et al. Viral load monitoring and antiretroviral treatment outcomes in a pediatric HIV cohort in Ghana. BMC Infect Dis. 2016;16(1):58.

18. Moore DM, Awor A, Downing R, Kaplan J, Montaner JS, Hancock J, Were W, Mermin J. CD4+ T-cell count monitoring does not accurately identify HIVinfected adults with virologic failure receiving antiretroviral therapy. JAIDS Journal of Acquired Immune Deficiency Syndromes. 2008 ;49(5):47784.

19. Le NK, et al. Assessment of WHO criteria for identifying ART treatment failure in Vietnam from 2007 to 2011. PLoS One. 2017;12(9):e0182688. https://doi.org/10.1371/journal.pone.0182688.

20. World Health, O. Antiretroviral therapy for HIV infection in adults and adolescents: recommendations for a public health approach - 2010 revision. Geneva: World Health Organization; 2010.

21. World Health, O. Consolidated guidelines on the use of antiretroviral drugs for treating and preventing HIV infection: recommendations for a public health approach. 2nd ed. Geneva: World Health Organization; 2016.

22. Prevention, A.G.A.f.H., Viral load testing for HIV treatment monitoring in Uganda. 2015.

23. Mark NS, Rachel M, Kaimal A, Frank M, Harriet T, Isaac L, Lamorde M, Barbara C. Evaluation of the management of patients with detectable viral load after the implementation of routine viral load monitoring in an urban HIV clinic in Uganda. AIDS Res Treat. 2019;2019(Article ID 9271450):5.

24. Bunupuradah T, Puthanakit T, Kosalaraksa P, Kerr S, Boonrak P, Prasitsuebsai W, Lumbiganon P, Mengthaisong T, Phasomsap C, Pancharoen C, Ruxrungtham K, Ananworanich J. Immunologic and virologic failure after first-line NNRTI-based antiretroviral therapy in Thai HIV-infected children. AIDS Res Ther. 2011;8(1):40. https://doi.org/10.1186/1742-6405-8-40.

25. Rawizza HE, Chaplin B, Meloni ST, Eisen G, Rao T, Sankale JL, Dieng-Sarr A, Agbaji O, Onwujekwe DI, Gashau W, Nkado R, Ekong E, Okonkwo P, Murphy RL, Kanki PJ, for the APIN PEPFAR Team. Immunologic criteria are poor predictors of virologic outcome: implications for HIV treatment monitoring in resource-limited settings. Clin Infect Dis. 2011;53(12):1283-90. https://doi. org/10.1093/cid/cir729.

26. Ruel TD, Kakuru A, Ikilezi G, Mwangwa F, Dorsey G, Rosenthal PJ, Charlebois E, Havlir D, Kamya M, Achan J. Virologic and immunologic outcomes of HIVinfected Ugandan children randomized to lopinavir/ritonavir or nonnucleoside reverse transcriptase inhibitor therapy. J Acquir Immune Defic Syndr. 2014;65(5):535-41. https://doi.org/10.1097/QAl. 0000000000000071.

27. Rutherford GW, Anglemyer A, Easterbrook PJ, Horvath T, Vitoria M, Penazzato M, Doherty MC. Predicting treatment failure in adults and children on antiretroviral therapy: a systematic review of the performance characteristics of the $2010 \mathrm{WHO}$ immunologic and clinical criteria for virologic failure. Aids. 2014;28(Suppl 2):S161-9. https://doi.org/10.1097/QAD. 0000000000000236.

28. Salazar-Vizcaya L, Keiser O, Technau K, Davies MA, Haas AD, Blaser N, Cox V, Eley B, Rabie H, Moultrie H, Giddy J, Wood R, Egger M, Estill J. Viral load versus CD4(+) monitoring and 5-year outcomes of antiretroviral therapy in HIV-positive children in southern Africa: a cohort-based modelling study. Aids. 2014;28(16):2451-60. https://doi.org/10.1097/QAD.0000000000000446.

29. Shrier I, Platt RW. Reducing bias through directed acyclic graphs. BMC Med Res Methodol. 2008;8(1):70. https://doi.org/10.1186/1471-2288-8-70.

30. van Buuren $\mathrm{S}$, Groothuis-Oudshoorn K. Mice: multivariate imputation by chained equations in R. J Stat Softw. 2011;1(3):2011.

31. $\mathrm{WHO}$, Consolidated Guidelines on the Use of Antiretroviral Drugs for Treating and Preventing HIV Infection. 2016. p. 22.

32. Barry O, Powell J, Renner L, Bonney EY, Prin M, Ampofo W, Kusah J, Goka B, Sagoe KWC, Shabanova V, Paintsil E. Effectiveness of first-line antiretroviral 
therapy and correlates of longitudinal changes in CD4 and viral load among HIV-infected children in Ghana. BMC Infect Dis. 2013;13(1):476. https://doi.org/10.1186/1471-2334-13-476.

33. Szubert AJ, Prendergast AJ, Spyer MJ, Musiime V, Musoke P, BwakuraDangarembizi M, Nahirya-Ntege P, Thomason MJ, Ndashimye E, Nkanya I, Senfuma O, Mudenge B, Klein N, Gibb DM, Walker AS, the ARROW Trial Team. Virological response and resistance among HIV-infected children receiving long-term antiretroviral therapy without virological monitoring in Uganda and Zimbabwe: observational analyses within the randomised ARROW trial. PLoS Med. 2017;14(11):e1002432. https://doi.org/10.1371/ journal.pmed.1002432.

34. Dow DE, Shayo AM, Cunningham CK, Reddy EA. Durability of antiretroviral therapy and predictors of virologic failure among perinatally HIV-infected children in Tanzania: a four-year follow-up. BMC Infect Dis. 2014;14(1):567. https://doi.org/10.1186/s12879-014-0567-3.

35. Moorthy A, Kuhn L, Coovadia A, Meyers T, Strehlau R, Sherman G, Tsai WY, Chen YH, Abrams EJ, Persaud D. Induction therapy with protease-inhibitors modifies the effect of Nevirapine resistance on Virologic response to Nevirapine-based HAART in children. Clin Infect Dis. 2011;52(4):514-21. https://doi.org/10.1093/cid/ciq161.

36. Lockman S, Shapiro RL, Smeaton LM, Wester C, Thior I, Stevens L, Chand F, Makhema J, Moffat C, Asmelash A, Ndase P, Arimi P, van Widenfelt E, Mazhani L, Novitsky V, Lagakos S, Essex M. Response to antiretroviral therapy after a single, peripartum dose of nevirapine. N Engl J Med. 2007; 356(2):135-47. https://doi.org/10.1056/NEJMoa062876.

37. Violari A, Lindsey JC, Hughes MD, Mujuru HA, Barlow-Mosha L, Kamthunzi P, Chi BH, Cotton MF, Moultrie H, Khadse S, Schimana W, Bobat R, Purdue L, Eshleman SH, Abrams EJ, Millar L, Petzold E, Mofenson LM, Jean-Philippe P, Palumbo P. Nevirapine versus ritonavir-boosted lopinavir for HIV-infected children. N Engl J Med. 2012;366(25):2380-9. https://doi.org/10.1056/ NEJMoa1113249

38. Palumbo P, Lindsey JC, Hughes MD, Cotton MF, Bobat R, Meyers T, Bwakura-Dangarembizi M, Chi BH, Musoke P, Kamthunzi P, Schimana W, Purdue L, Eshleman SH, Abrams EJ, Millar L, Petzold E, Mofenson LM, JeanPhilippe P, Violari A. Antiretroviral treatment for children with peripartum nevirapine exposure. N Engl J Med. 2010;363(16):1510-20. https://doi.org/1 0.1056/NEJMoa1000931.

39. Greig JE, du Cros PA, Mills C, Ugwoeruchukwu W, Etsetowaghan A, Grillo A, Tayo-Adetoro A, Omiyale K, Spelman T, O'Brien DP. Predictors of raised viral load during antiretroviral therapy in patients with and without prior antiretroviral use: a cross-sectional study. PLoS One. 2013;8(8):p.e71407.

40. Adams J, Patel N, Mankaryous N, Tadros M, Miller CD. Nonnucleoside reverse transcriptase inhibitor resistance and the role of the secondgeneration agents. Annals of Pharmacotherapy. 2010;44(1):157-65.

41. Chandrasekaran P, Shet A, Srinivasan R, Sanjeeva GN, Subramanyan S, Sunderesan S, Ramesh K, Gopalan B, Suresh E, Poornagangadevi N, Hanna LE, Chandrasekar C, Wanke C, Swaminathan S. Long-term virological outcome in children receiving first-line antiretroviral therapy. AIDS Res Ther. 2018;15(1):23. https://doi.org/10.1186/s12981-018-0208-9.

42. Collins IJ, Wools-Kaloustian K, Goodall R, Smith C, Abrams EJ, Ben-Farhat J, Balkan S, Davies MA, Edmonds A, Leroy V, Nuwagaba-Biribonwoha H, Patel K, Paul ME, Pinto J, Rojo Conejo P, Sohn A, van Dyke R, Vreeman R, Maxwell N, Timmerman V, Duff C, Judd A, Seage III G, Williams P, Gibb DM, Bekker LG, Mofenson L, Vicari M, Essajee S, Mohapi EQ, Kazembe PN, Hlatshwayo M, Lumumba M, Kekitiinwa-Rukyalekere A, Wanless S, Matshaba MS, Goetghebuer T, Thorne C, Warszawski J, Galli L, Geelen S, Giaquinto C, Marczynska M, Marques L, Prata F, Ene L, Okhonskaia L, Noguera-Julian A, Naver L, Rudin C, Jourdain G, Volokha A, Rouzier V, Succi R, Chokephaibulkit K, Kariminia A, Yotebieng M, Lelo P, Lyamuya R, Marete I, Oyaro P, Boulle A, Malisita K, Fatti G, Haas AD, Desmonde S, Dicko F, Abzug MJ, Levin M, Oleske J, Chernoff M, Traite S, Purswani M, Teasdale C, Chadwick E. Incidence of switching to second-line antiretroviral therapy and associated factors in children with HIV: an international cohort collaboration. Lancet HIV. 2019;6(2):e105-15. https://doi.org/10.1016/S2352-3018(18)30319-9.

\section{Publisher's Note}

Springer Nature remains neutral with regard to jurisdictional claims in published maps and institutional affiliations.

\section{Ready to submit your research? Choose BMC and benefit from:}

- fast, convenient online submission

- thorough peer review by experienced researchers in your field

- rapid publication on acceptance

- support for research data, including large and complex data types

- gold Open Access which fosters wider collaboration and increased citations

- maximum visibility for your research: over $100 \mathrm{M}$ website views per year

At BMC, research is always in progress.

Learn more biomedcentral.com/submissions 